REVIEW

\title{
Association between serum TSH concentration within the normal range and adiposity
}

\author{
Amanda de Moura Souza and Rosely Sichieri \\ Department of Epidemiology, Institute of Social Medicine, State University of Rio de Janeiro, Rua São Francisco Xavier, 524, $7^{\circ}$ andar, Bloco E. Cep \\ 20550-900 Rio de Janeiro, RJ, Brazil \\ (Correspondence should be addressed to A de Moura Souza; Email: amandamoura@msn.com)
}

\begin{abstract}
Background: Overt hypothyroidism is clearly related to body weight gain and greater adiposity, but the range of hormonal change in serum TSH concentration associated with weight gain remains a focus of debate. Aim: The aim of this review was to assess studies that evaluated the relationship between anthropometric measures and serum TSH concentration in euthyroid subjects.

Methods: Studies held on the Ovid MEDLINE database were searched and original articles published from 2000 to 2010 were included. The literature search was restricted to studies conducted in humans aged 18 years or older and written in English, Spanish, or Portuguese. Studies that evaluated the association between anthropometric measures and serum TSH within the normal range as the primary objective, as well as additional analysis, were included.

Results: A total of 29 studies met the inclusion criteria. Of the 29 studies, 18 showed a positive relationship between measures of adiposity and serum TSH. Despite the plausibility of this association, only two studies reported longitudinal findings. The influence of smoking on the association between serum TSH and anthropometric measures was evaluated in only three studies and remains unclear.

Conclusion: Thus, further longitudinal studies are needed to better understand the mechanisms by which TSH concentration might impact body weight.
\end{abstract}

European Journal of Endocrinology 165 11-15

\section{Introduction}

Overt hypothyroidism is clearly related to body weight and greater adiposity (1), but the range of hormonal changes related to weight gain remains a subject of debate. Thyroid hormones affect many metabolic processes, and subclinical hypothyroidism has been associated with both hypertension (2) and hypercholesterolemia (3).

Among the several hormonal changes that occur in obesity, serum TSH concentration has been the focus of recent studies with conflicting results. The potential impact of minor changes in thyroid function on body weight and other anthropometric measures, especially in euthyroid subjects (4-6), has been investigated. Thus, the definition of the upper limit of normal serum TSH range has been under intense debate in the literature $(7,8)$. It has been suggested that the upper limit of the normal serum TSH range be reduced to $2.5 \mathrm{mU} / \mathrm{l}(8)$, but a large epidemiologic study in a population with no evidence of thyroid disease, seronegative for thyroid autoantibodies, without history of thyroid medications, and normal on thyroid ultrasound, indicated a serum TSH value of $4.0 \mathrm{mU} / \mathrm{l}$ as the upper reference limit (7).

To our knowledge, there are no reviews focusing specifically on the association between changes in anthropometric measures and serum TSH concentration among subjects with normal thyroid function or subclinical thyroid disease. Thus, the main objective of this review was to assess studies that evaluated the relationship between anthropometric measures and serum TSH concentrations.

\section{Method}

\section{Search strategy}

Articles held on the Ovid MEDLINE database were searched and original articles published from 2000 to 2010 were included. The last search was held on 05 May 2010. The following search terms were used: 'TSH' or 'thyroid-stimulating hormone' or 'thyrotropin' or 'thyroid-stimulating hormone' or 'hormone, thyroidstimulating' or 'thyreotropin' or 'hormones, thyroid' or 'subclinical hypothyroidism' or 'hypothyroidism' or 'hyperthyroidism' or 'thyroid disease' and 'BMI' or 'body mass index' or 'obesity' or 'overweight' 'weight gain' or 'weight loss' or 'skinfold thickness' or 'waisthip ratio' or 'abdominal fat'. Our search was restricted to studies conducted in humans aged 18 years or older and written in English, Spanish, or Portuguese 
languages. Studies evaluating the association between anthropometric measures and serum TSH among subjects with normal thyroid function or subclinical thyroid disease were included. Articles that lacked information about the association between serum TSH and anthropometric measures were excluded. There were no restrictions regarding study designs or sample size.

\section{Results}

Figure 1 depicts the selection process for studies included in this review. A total of 29 studies met the inclusion criteria. These studies were conducted in several countries: five were conducted in United States; four in Italy; three in Korea and The Netherlands; two in Greece, Norway, and Spain; and one in each of the following countries: Australia, Brazil, Denmark, Germany, India, Japan, the Czech Republic, and Turkey.

A total of 56630 subjects between the ages of 18 and 89 years participated in the studies reviewed. The study sample includes 33\% males, $60 \%$ females, and $7 \%$ unreported gender. This preponderance of females could be explained by the higher prevalence of thyroid disease and obesity among women compared with men. The minimum reference value of TSH ranged from 0.17 to $0.5 \mathrm{mU} / \mathrm{l}$, whereas the maximum reference value of TSH ranged from 3.5 to $5.5 \mathrm{mU} / \mathrm{l}$.

Anthropometric measures used in the studies included BMI (4-6, 9-30), body weight $(15,31,32)$, waist circumference $(9,14,15,23,29,33)$, waist-hip ratio $(9,15)$, hip $(23)$, body fat percentage $(13,15,17$, $21,23,29,32)$, subcutaneous $(9,15,21,27)$ and central (21) fat, and fat mass index (fat mass $(\mathrm{kg}) /$ height $\left.(\mathrm{m})^{2}\right)(29)$.

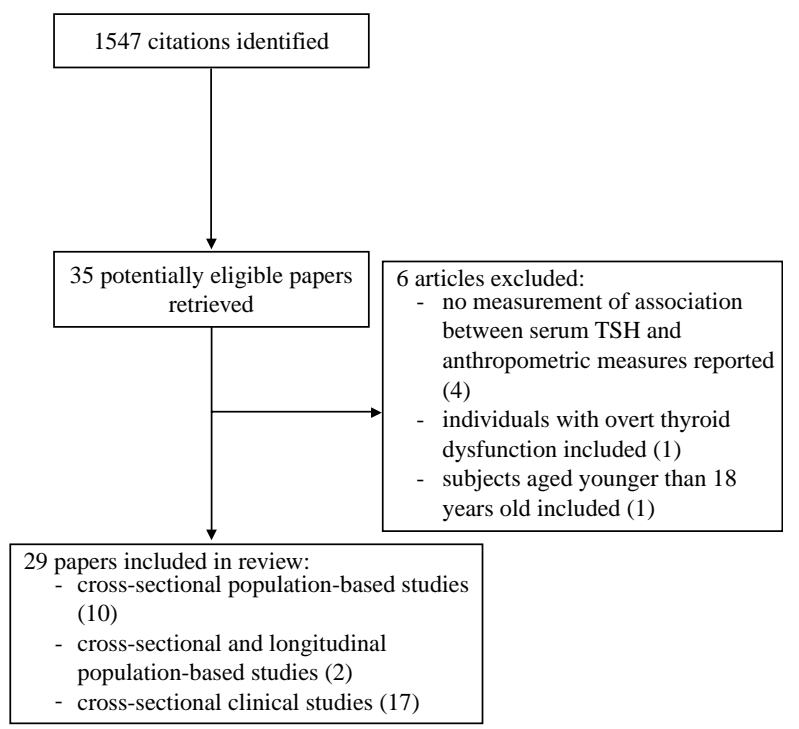

Figure 1 Flow chart of process for selection of eligible studies examining the association between body mass index (BMI) and serum TSH concentrations within the normal range.
Although race is known to be associated with serum TSH concentration (34) and adiposity (35), this demographic factor was not reported in $87.8 \%$ of participants. However, as most of the studies were performed in European countries, the majority of subjects were probably Caucasian.

\section{Clinical studies}

Of the total studies, 17 were based on clinical samples (see Supplementary Table 1, see section on supplementary data given at the end of this article), 11 of which found to have a positive association between serum TSH concentration and measures of adiposity (10-12, 17, 18, 21, 22, 27, 30, 32). Of the 11 studies, seven included only obese or overweight subjects.

The highest correlation coefficient in the association between BMI and serum TSH was found in studies that included only euthyroid obese women $(r=0.44$, $P=0.01$ ) (18) or morbidly obese men and women $(r=0.91 ; P$ value $<0.001)(12)$.

The coefficient correlation in studies performed among obese women was twice greater than the coefficient correlation found in the study performed among obese males $(r=0.22, P<0.05)$ (17).

None of the studies evaluated the association between measures of adiposity and serum TSH according to skin color.

\section{Population-based studies}

Results of population-based studies are shown in Supplementary Table 1. Of the twelve studies, seven found a positive association between serum TSH and measures of adiposity $(4,6,15,20,24,26,31)$.

Both cross-sectional and prospective findings were reported in two studies $(6,31)$. The first of these found a positive association between BMI and serum TSH only among non-smokers in both cross-sectional and longitudinal analysis (6). The other study found a positive association between body weight and serum TSH concentrations among men and women (31).

The largest population-based study was carried out in Norway and involved 27097 euthyroid subjects. In this Norwegian study, BMI was positively associated with serum TSH $(\beta=0.41, P<0.001$ for women; $\beta=0.48$, $P<0.001$ for men) (4).

Three studies evaluated the association between measures of adiposity and serum TSH according to smoking status (4-6). Nyrnes et al. (6) found a positive association between BMI and serum TSH only among non-smokers. Makepeace et al. (5), however, failed to find any association with smoking status. In contrast, Asvold et al. (4) found a positive and statistically significant association between BMI and serum TSH among both non-smokers and smokers. In men, 
however, this association was stronger among current smokers $(\beta=0.81, \quad P<0.001)$ than non-smokers $(\beta=0.32, P<0.001)$.

\section{Discussion}

The published literature investigating the association between anthropometric measures and serum TSH within the normal range presents conflicting results. However, 17 of the 29 reviewed studies found a positive association between anthropometric measures and serum TSH, and the two longitudinal population-based studies showed a positive association between serum TSH concentration and BMI or body weight $(6,31)$.

The plausibility of this association has been discussed and could be mediated by TSH action directly stimulating preadipocyte differentiation, thus inducing adipogenesis $(36,37)$. Another hypothesis is that the association between serum TSH and body weight may be due to leptin (38). In agreement with the leptin hypothesis, a recent study in treated thyroid cancer patient found an increase in serum leptin after acute recombinant human TSH administration, which was proportional to adipose mass (39). Also, the highest correlations in the association between BMI and serum TSH concentration $(r=0.91)$ was shown among morbidly obese participants (12). In line with these findings, Rotondi et al. (30) found higher values of serum TSH among euthyroid morbid obese subjects when compared with euthyroid normal-weight patients and morbidly obese subjects with hypothyroidism showed lower level of anti-TPO. Thus, the authors suggested that the raised serum TSH concentrations, especially in morbid obesity, may be independent of thyroid function.

The effects of excess body weight on thyroid could differ between lower grades of overweight and morbid obesity (30), which could in part explain the different findings reported by the reviewed studies, because these articles include people with different levels of overweight or obesity that could blur a possible effect of TSH. In addition, the variability in anti-TPO levels could also explain the discrepancy of results among the reviewed studies.

Among the reviewed studies, the maximum reference value of $\mathrm{TSH}$ ranged from 3.5 to $5.5 \mathrm{mU} / \mathrm{l}$. As previously mentioned, the definition of the maximum reference value of the TSH range has been the subject of intense debate. Hamilton et al. (7) performed a population-based study with subjects without evidence of thyroid disease and suggested an upper reference limit of serum TSH of $4 \mathrm{mU} / \mathrm{l}$. However, 18 of the 29 examined studies considered an upper-limit TSH value of over $4 \mathrm{mU} / \mathrm{l}$. This variability in limits might explain the lack of association between BMI and TSH in 11 $(5,9,13,16,19,23,25,28,29,33,40)$ of the 29 examined studies. Another source of discrepancy is the fact that almost half of the studies did not perform adjustment for potential confounders.
Limitations of the reviewed articles included the fact that most studies were conducted in a clinical setting, whereas only two reported a longitudinal design $(6,31)$. Furthermore, adjustment for potential confounders was also limited in the reviewed studies whereby $14(9,10,13,14,16-19,21-23,27,29,30)$ of the 29 studies performed no such adjustments.

Age, sex, and smoking were the variables adjusted for. Sex and smoking are considered potential confounders as well as effect modifiers of the association between BMI and serum TSH. It is well known that the prevalence of thyroid disorders is higher among women than men (41). Consequently, participants in the reviewed studies were mainly women and the majority of reports evaluated the association between BMI and TSH adjusting by sex. Among those studies that performed analyses stratified according to sex, Dvorakova et al. (15) found a significant association between BMI and serum TSH only among women, whereas the other studies found no significant differences by sex.

Smoking is related to both serum TSH and BMI. Smokers have lower serum TSH concentration (42) and lower BMI than non-smokers (43). Of the 29 studies, four considered smoking a potential confounder, three of which performed analysis stratified according to smoking status. The results of these studies, however, were inconclusive. A study performed in Norway found a positive association between BMI and serum TSH only among non-smokers (6). In contrast, another study also performed in Norway found the same association among both non-smokers and smokers. Nevertheless, the association between BMI and serum TSH in men was stronger among current smokers than non-smokers (4).

In summary, despite the plausibility of the association between serum TSH within the normal range and anthropometric measures, almost half of the studies did not find a positive relationship. However, the findings from the large studies and the longitudinal investigations indicated a positive association. The influence of smoking on the association between serum TSH and anthropometric measures was evaluated in only three studies and remains unclear. Thus, further controlled longitudinal studies are needed to better understand the mechanisms by which TSH concentration might impact body weight.

\section{Supplementary data}

This is linked to the online version of the paper at http://dx.doi.org/ 10.1530/EJE-11-0261.

\section{Declaration of interest}

The authors declare that there is no conflict of interest that could be perceived as prejudicing the impartiality of the research reported.

\section{Funding}

The study was funded by Brazilian Coordination for Training of University Personnel (CAPES). 


\section{References}

1 Hoogwerf BJ \& Nuttall FQ. Long-term weight regulation in treated hyperthyroid and hypothyroid subjects. American Journal of Medicine $1984 \mathbf{7 6}$ 963-970. (doi:10.1016/00029343(84)90842-8)

2 Liu D, Jiang F, Shan Z, Wang B, Wang J, Lai Y, Chen Y, Li M, Liu H, Li C, Xue H, Li N, Yu J, Shi L, Bai X, Hou X, Zhu L, Lu L, Wang S, Xing Q \& Teng W. A cross-sectional survey of relationship between serum TSH level and blood pressure. Journal of Human Hypertension 200924 134-138. (doi:10.1038/jhh.2009.44)

3 Pirich $\mathrm{C}$, Mullner $\mathrm{M} \&$ Sinzinger $\mathrm{H}$. Prevalence and relevance of thyroid dysfunction in 1922 cholesterol screening participants. Journal of Clinical Epidemiology 200053 623-629. (doi:10.1016/ S0895-4356(99)00187-0)

4 Asvold BO, Bjoro T \& Vatten LJ. Association of serum TSH with high body mass differs between smokers and never-smokers. Journal of Clinical Endocrinology and Metabolism 200994 5023-5027. (doi:10.1210/jc.2009-1180)

5 Makepeace AE, Bremner AP, O'Leary P, Leedman PJ, Feddema P, Michelangeli V \& Walsh JP. Significant inverse relationship between serum free $\mathrm{T}_{4}$ concentration and body mass index in euthyroid subjects: differences between smokers and nonsmokers. Clinical Endocrinology 200869 648-652. (doi:10.1111/j.13652265.2008.03239.x)

6 Nyrnes A, Jorde R \& Sundsfjord J. Serum TSH is positively associated with BMI. International Journal of Obesity $2006 \mathbf{3 0}$ 100-105. (doi:10.1038/sj.ijo.0803112)

7 Hamilton TE, Davis S, Onstad L \& Kopecky KJ. Thyrotropin levels in a population with no clinical, autoantibody, or ultrasonographic evidence of thyroid disease: implications for the diagnosis of subclinical hypothyroidism. Journal of Clinical Endocrinology and Metabolism 200893 1224-1230. (doi:10.1210/jc.2006-2300)

8 Wartofsky L \& Dickey RA. The evidence for a narrower thyrotropin reference range is compelling. Journal of Clinical Endocrinology and Metabolism 2005 90 5483-5488. (doi:10.1210/jc.2005-0455)

9 Alevizaki M, Saltiki K, Voidonikola P, Mantzou E, Papamichael C \& Stamatelopoulos K. Free thyroxine is an independent predictor of subcutaneous fat in euthyroid individuals. European Journal of Endocrinology 2009161 459-465. (doi:10.1530/EJE-09-0441)

10 Ambrosi B, Masserini B, Iorio L, Delnevo A, Malavazos AE, Morricone L, Sburlati LF \& Orsi E. Relationship of thyroid function with body mass index and insulin-resistance in euthyroid obese subjects. Journal of Endocrinological Investigation 2010 33 640-643. (doi:10.3275/6952)

11 Bastemir M, Akin F, Alkis E \& Kaptanoglu B. Obesity is associated with increased serum TSH level, independent of thyroid function. Swiss Medical Weekly 2007137 431-434.

12 Chikunguwo $\mathrm{S}$, Brethauer $\mathrm{S}$, Nirujogi V, Pitt T, Udomsawaengsup S, Chand B \& Schauer P. Influence of obesity and surgical weight loss on thyroid hormone levels. Surgery for Obesity and Related Diseases 20073 631-635 (discussion 635-636). (doi:10.1016/j.soard.2007.07.011)

13 Choi SH, Lee YJ, Park YJ, Kim KW, Lee EJ, Lim S, Park do J, Kim SE, Park KS, Jang HC \& Cho BY. Retinol binding protein- 4 elevation is associated with serum thyroid-stimulating hormone level independently of obesity in elderly subjects with normal glucose tolerance. Journal of Clinical Endocrinology and Metabolism 200893 2313-2318. (doi:10.1210/jc.2007-2536)

14 De Pergola G, Ciampolillo A, Paolotti S, Trerotoli P \& Giorgino R. Free triiodothyronine and thyroid stimulating hormone are directly associated with waist circumference, independently of insulin resistance, metabolic parameters and blood pressure in overweight and obese women. Clinical Endocrinology $2007 \mathbf{6 7}$ 265-269. (doi:10.1111/j.1365-2265.2007.02874.x)

15 Dvorakova M, Hill M, Cerovska J, Pobisova Z, Bilek R, Hoskovcova P, Zamrazil V \& Hainer V. Relationship between pituitary-thyroid axis hormones and anthropometric parameters in Czech adult population. Physiological Research $2008 \mathbf{5 7}$ (Supplement 1) S127-S134.
16 Fernandez-Real JM, Lopez-Bermejo A, Castro A, Casamitjana R \& Ricart W. Thyroid function is intrinsically linked to insulin sensitivity and endothelium-dependent vasodilation in healthy euthyroid subjects. Journal of Clinical Endocrinology and Metabolism 200691 3337-3343. (doi:10.1210/jc.2006-0841)

17 Galofre JC, Pujante P, Abreu C, Santos S, Guillen-Grima F, Fruhbeck G \& Salvador J. Relationship between thyroid-stimulating hormone and insulin in euthyroid obese men. Annals of Nutrition and Metabolism 200853 188-194. (doi:10.1159/000172981)

18 Iacobellis G, Ribaudo MC, Zappaterreno A, Iannucci CV \& Leonetti F. Relationship of thyroid function with body mass index, leptin, insulin sensitivity and adiponectin in euthyroid obese women. Clinical Endocrinology 200562 487-491. (doi:10. 1111/j.1365-2265.2005.02247.x)

19 Kim DJ, Khang YH, Koh JM, Shong YK \& Kim GS. Low normal TSH levels are associated with low bone mineral density in healthy postmenopausal women. Clinical Endocrinology 2006 64 86-90. (doi:10.1111/j.1365-2265.2005.02422.x)

20 Knudsen N, Laurberg P, Rasmussen LB, Bulow I, Perrild H, Ovesen L \& Jorgensen T. Small differences in thyroid function may be important for body mass index and the occurrence of obesity in the population. Journal of Clinical Endocrinology and Metabolism 200590 4019-4024. (doi:10.1210/jc.2004-2225)

21 Kok P, Roelfsema F, Frolich M, Meinders AE \& Pijl H. Spontaneous diurnal thyrotropin secretion is enhanced in proportion to circulating leptin in obese premenopausal women. Journal of Clinical Endocrinology and Metabolism 200590 6185-6191. (doi:10.1210/jc.2005-0003)

22 Kumar HK, Yadav RK, Prajapati J, Reddy CV, Raghunath M \& Modi KD. Association between thyroid hormones, insulin resistance, and metabolic syndrome. Saudi Medical Journal 2009 30 907-911.

23 Michalaki MA, Vagenakis AG, Leonardou AS, Argentou MN, Habeos IG, Makri MG, Psyrogiannis AI, Kalfarentzos FE \& Kyriazopoulou VE. Thyroid function in humans with morbid obesity. Thyroid 200616 73-78. (doi:10.1089/thy.2006.16.73)

24 Morris MS. The association between serum thyroid-stimulating hormone in its reference range and bone status in postmenopausal American women. Bone 200740 1128-1134. (doi:10.1016/j. bone.2006.12.001)

25 Peeters RP, van der Deure WM, van den Beld AW, van Toor $H$ Lamberts SW, Janssen JA, Uitterlinden AG \& Visser TJ The Asp727Glu polymorphism in the TSH receptor is associated with insulin resistance in healthy elderly men. Clinical Endocrinology 200766 808-815. (doi:10.1111/j.1365-2265. 2007.02817.x)

26 Ruhla S, Weickert MO, Arafat AM, Osterhoff M, Isken F, Spranger J, Schofl C, Pfeiffer AF \& Mohlig M. A high normal TSH is associated with the metabolic syndrome. Clinical Endocrinology $2010 \mathbf{7 2}$ 696-701. (doi:10.1111/j.1365-2265.2009.03698.x)

27 Ruscica M, Dozio E, Gandini S, Gnocchi P, Devalle GG, Motta M, Roti E \& Magni P. Total, free and bound leptin and thyroid function in elderly women with different body weights. Clinical Endocrinology $2008 \mathbf{6 8}$ 1002-1008. (doi:10.1111/j.13652265.2007.03133.x)

28 Shon HS, Jung ED, Kim SH \& Lee JH. Free $\mathrm{T}_{4}$ is negatively correlated with body mass index in euthyroid women. Korean Journal of Internal Medicine 200823 53-57. (doi:10.3904/kjim. 2008.23.2.53)

29 Teixeira PF, Cabral MD, Silva NA, Soares DV, Braulio VB, Couto AP, Henriques JL, Costa AJ, Buescu A \& Vaisman M. Serum leptin in overt and subclinical hypothyroidism: effect of levothyroxine treatment and relationship to menopausal status and body composition. Thyroid 200919 443-450. (doi:10.1089/thy. 2007.0393)

30 Rotondi M, Leporati P, La Manna A, Pirali B, Mondello T, Fonte R, Magri F \& Chiovato L. Raised serum TSH levels in patients with morbid obesity: is it enough to diagnose subclinical hypothyroidism? European Journal of Endocrinology $2009 \mathbf{1 6 0} 403-408$. (doi:10.1530/EJE-08-0734) 
31 Fox CS, Pencina MJ, D’Agostino RB, Murabito JM, Seely EW, Pearce EN \& Vasan RS. Relations of thyroid function to body weight: cross-sectional and longitudinal observations in a community-based sample. Archives of Internal Medicine 2008 168 587-592. (doi:10.1001/archinte.168.6.587)

32 Ortega E, Pannacciulli N, Bogardus C \& Krakoff J. Plasma concentrations of free triiodothyronine predict weight change in euthyroid persons. American Journal of Clinical Nutrition $2007 \mathbf{8 5}$ 440-445.

33 Roos A, Bakker SJ, Links TP, Gans RO \& Wolffenbuttel BH. Thyroid function is associated with components of the metabolic syndrome in euthyroid subjects. Journal of Clinical Endocrinology and Metabolism 2007 92 491-496. (doi:10.1210/jc.2006-1718)

34 Aoki Y, Belin RM, Clickner R, Jeffries R, Phillips L \& Mahaffey KR. Serum TSH and total $\mathrm{T}_{4}$ in the United States population and their association with participant characteristics: National Health and Nutrition Examination Survey (NHANES 1999-2002). Thyroid 200717 1211-1223. (doi:10.1089/thy.2006.0235)

35 Lewis TT, Everson-Rose SA, Sternfeld B, Karavolos K, Wesley D \& Powell LH. Race, education, and weight change in a biracial sample of women at midlife. Archives of Internal Medicine 2005 165 545-551. (doi:10.1001/archinte.165.5.545)

36 Sorisky A, Bell A \& Gagnon A. TSH receptor in adipose cells. Hormone and Metabolic Research 200032 468-474. (doi:10.1055/ s-2007-978672)

37 Valyasevi RW, Harteneck DA, Dutton CM \& Bahn RS. Stimulation of adipogenesis, peroxisome proliferator-activated receptorgamma (PPARgamma), and thyrotropin receptor by PPARgamma agonist in human orbital preadipocyte fibroblasts. Journal of Clinical Endocrinology and Metabolism 200287 2352-2358. (doi:10.1210/jc.87.5.2352)

38 Feldt-Rasmussen U. Thyroid and leptin. Thyroid $2007 \mathbf{1 7}$ 413-419. (doi:10.1089/thy.2007.0032)
39 Santini F, Galli G, Maffei M, Fierabracci P, Pelosini C, Marsili A, Giannetti M, Castagna M, Checchi S, Molinaro E, Piaggi P, Pacini F, Elisei R, Vitti P \& Pinchera A. Acute exogenous TSH administration stimulates leptin secretion in vivo. European Journal of Endocrinology 201072 696-701.

40 Takashima N, Niwa Y, Mannami T, Tomoike H \& Iwai N. Characterization of subclinical thyroid dysfunction from cardiovascular and metabolic viewpoints: the Suita study. Circulation Journal 200771 191-195. (doi:10.1253/circj.71.191)

41 Hollowell JG, Staehling NW, Flanders WD, Hannon WH, Gunter EW, Spencer CA \& Braverman LE. Serum TSH, T(4), and thyroid antibodies in the United States population (1988 to 1994): National Health and Nutrition Examination Survey (NHANES III). Journal of Clinical Endocrinology and Metabolism $2002 \mathbf{8 7}$ 489-499. (doi:10.1210/jc.87.2.489)

42 Belin RM, Astor BC, Powe NR \& Ladenson PW. Smoke exposure is associated with a lower prevalence of serum thyroid autoantibodies and thyrotropin concentration elevation and a higher prevalence of mild thyrotropin concentration suppression in the third National Health and Nutrition Examination Survey (NHANES III). Journal of Clinical Endocrinology and Metabolism 200489 6077-6086. (doi:10.1210/jc.2004-0431)

43 John U, Hanke M, Rumpf HJ \& Thyrian JR. Smoking status, cigarettes per day, and their relationship to overweight and obesity among former and current smokers in a national adult general population sample. International Journal of Obesity 200529 1289-1294. (doi:10.1038/sj.ijo.0803028)

Received 18 April 2011

Accepted 27 April 2011 